\title{
Estimating Money Demand in Cambodia
}

\section{Long Vorlak}

School of Economics, Northeast Normal University, Changchun, Jilin, China. vorleak_long@yahoo.com

\section{Ignatius Abasimi}

School of Economics, Northeast Normal University, Changchun, Jilin, China. abasimiignatus@gmail.com

\section{Agus Salim}

School of Economics, Northeast Normal University, Changchun, Jilin, China.

\begin{abstract}
This study extended the existing to analysed the impact of money demand in Cambodia. In addition, to analyse the stable demand for money, the study used autoregressive distributed lag model (ARDL) approach to estimate the short and long run causality of the variables considered in the econometrics model. The results based on the bounds testing procedure confirm that a stable, long-run relationship exists between demand for money and its determinants: real income, inflation rate and nominal exchange rate. The empirical results reveal that there is a unique cointegration and stable long-run relationship among money supply, income, inflation rate and exchange rate. And found that depreciation of domestic currency decreases the demand for money. The results also reveal that after incorporating the CUSUM and CUSUMSQ tests, money demand is stable between 1996 and 2016.
\end{abstract}

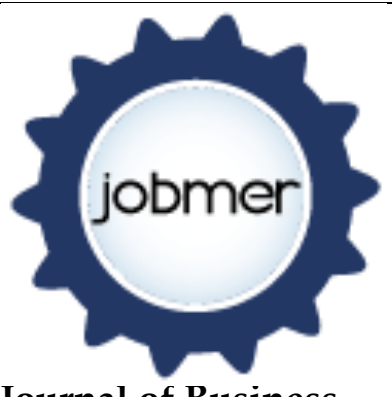

Journal of Business Management and Economic Research Vol.2, Issue.7, 2018 pp.32-42

Doi: 10.29226/TR1001.2018.47

Keywords: Money Demand, ARDL, econometrics model, cointegration, Cambodia

\section{Introduction}

Money demand models represent a natural benchmark against which monetary developments can be assessed. The importance of money demand has become a prominent research topic in economics in recent years due to its role in monetary policy formulation. There can be seen a wide array of literature on the demand for money, however, the focus of them is varied in accordance with time span, choice of variables and motives of money demand. The majority has emphasized that wealth and permanent income effect for money demand. The current income effects for money demand rather than permanent income, as people demand money mostly for transaction purpose. 
Monetarism today is mainly associated with the work of Friedman, who was among the generation of economists to accept Keynesian economics and then citizen it on its own terms. Friedman argued that "inflation is always and everywhere a monetary phenomenon". Also, he advocated a central bank policy aimed at keeping the supply and demand for money in equilibrium, as measured by growth in productivity and demand. Opponents of monetarism, including neo- Keynesian, demand for money is intrinsic to supply, while some conservative economists argue that demand for money cannot be predicted. Stieglitz has claimed that the relationship between inflation and money supply growth is weak when inflation is low (Friedman 1970)

Bahmani-Oskooee and Rehman (2005) used quarterly data from 1973 to 2000 to estimate the demand for money for seven Asian countries. Using ARDL approach and CUSUM and CUSUMSQ tests, they found that in some Asian countries even though real M1 or monetary aggregates are cointegrated with their determinants, the estimated parameters are unstable.

Akinlo (2006) used quarterly data over the period 1970:1-2002:4 and the ARDL approach combined with CUSUM and CUSUMSQ tests, to examine the cointegrating property and stability of M2 money demand for Nigeria. The results show M2 to be cointegrated with income, interest rate and exchange rate. Moreover, the results revealed somewhat stable relation mainly with the CUSUM test.

However, in addition to those fundamental determinants, new findings on the determinants of money demand have appeared in recent literature. In this paper, concentrations are on some variables that is believed to have a mixed effect on money demand in Cambodia, between data period from 1996 to 2016. The income, exchange rate, and inflation rate, have a considerable impact on the demand for money in Cambodia.

Moreover, having a stable money demand is very important, the existence of a well- specified and stable relationship between money and other macroeconomic variables, like price, and exchange rate can be perceived as a prerequisite for the use of monetary aggregates in the conduct of monetary policy. The main contribution of this paper is to demonstrate that whether exchange rate could make the wealth effect or expectation effect uncertain, it could have a positive or negative impact on money demand. Therefore, be considered as another determinant to be included in the money demand function due to the vital role it plays.

The organization of this term paper is stated as follows. Section 2 discusses about the model of money demand, briefly reviews a few relevant empirical 
works. Section 3 presents the estimation methodology, data, sample, estimate result; Section 4 is conclusion.

\section{Literature Review}

In the macroeconomic literature, it is common to assume that the demand for money depends on scale variable and the opportunity cost of holding it. The scale variable is usually defined as the real income or the real consumption expenditure, whereas the opportunity cost variable is usually considered as the interest rate on alternative asset. The general specifications of money demand function are assumed to take the following functional form.

$\frac{M D}{P}=L(w, z)$

Where $M D$ is the demand for money, $P$ is inflation (the price level), $w$ is the real income level which represents the scale variable, and $z$ is the opportunity cost variable. The variable, representing the opportunity cost, is usually considered as interest rate on alternative asset. However, when dealing with the case of developing countries whose financial sectors are not well developed, researchers often use the inflation rate as the proxy for the interest rate variable. Moreover, taking the currency substitution phenomenon into account, many studies on the demand for money in developing countries often include rate variable in the standard function of money. This inclusion of exchange rate variable in the standard function of money demand is first suggested by Mundell (1963).

For recent empirical studies on this kind of money demand function see, for example, Bahmani-Oskooee and Tanku (2006), AKinlo (2006). Some studies such as Zamaroczy and Sa (2002) Kang (2005) and Samreth (2008) provide information and empirical evidence on the currency substitution phenomenon in Cambodia. Taking this in to account, the money demand function becomes:

$\frac{M D}{P}=L(w, \pi, E x)$

Where $\pi$ and $E x$ are respectively the inflation and nominal exchange rates, the exchange rate, here is defined as the amount of domestic currency per unit of foreign currency. Therefore, the increase of Ex is interpreted as the depreciation of domestic currency against foreign currency. The estimation equation takes the following equation:

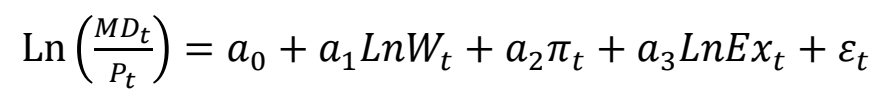

Where $\varepsilon$ represents the error term, based on the conventional economic theory, the income elasticity coefficient $b_{1}$, is expected to be positive; the coefficient of inflation, $b_{2}$ is expected to be negative. For the elasticity coefficient on the exchange rate variable $\left(a_{3}\right)$, it can be either positive or negative. If the increase 
exchange rate is perceived as the increase in wealth and leads to the rise of domestic money, the coefficient of exchange rate is positive. But, if the increase in exchange rate leads to the decrease in domestic money demand then the coefficient of exchange rate is negative. Additionally, the dummy variable representing the effect of political upheaval in Cambodia during 1997-1998 is included in equation (3). There for, we obtain the estimation equation below.

$\operatorname{Ln}\left(\frac{M D_{t}}{P_{t}}\right)=a_{0}+a_{1} \operatorname{Ln} W_{t}+a_{2} \pi_{t}+a_{3} \operatorname{LnEx_{t}}+a_{4} D U M_{t}+\varepsilon_{t}$

Where $D U M_{t}=1$ for period of $1997-1998$ and $D U M_{t}=0$ elsewhere

\section{Research Method}

\subsection{Data}

This study employs secondary data from World Bank for the analysis, and the sample period from 1996 to 2016. This sample period is chosen due to the availability of the data of all variables in the model. The demand of money balances are proxies by the monetary aggregate, M2 which consists of Cambodia Riel in circulation outside banks and Riel-denominated demand deposit in banking system.

\subsection{Model Specification and Estimation}

There are various techniques for cointegration analysis on money demand function. The popular approaches are: the well -known residual based approach proposed by Engle and Granger (1987) and the maximum likelihoodbased approach proposed by Johansen and Julius (1990). When there are more than two I(1) variables in the system, the maximum likelihood approach of Johansen and Julius has the advantage over residual- based approach of Engle and Ganger, however, both of the approaches requires that the variables have the same order of integration.

This study adopted ARDL approach to cointegration technique as the methodology for the empirical analysis on money demand function in Cambodia. The specified money demand function of equation (4) can be written as unrestricted error correction version of ARDL model below.

$$
\begin{aligned}
\Delta \operatorname{Ln}\left(\frac{\mathrm{Mdt}}{\mathrm{Pt}}\right)= & \alpha+\sum_{i=1}^{n} \delta \mathrm{i} \Delta \operatorname{Ln}\left(\frac{\mathrm{Mt}-\mathrm{i}}{\mathrm{Pt}-\mathrm{i}}\right)+\sum_{i=1}^{n} \beta_{j} \Delta w_{i-t}+\sum_{i=1}^{n} \lambda_{j} \Delta \pi_{t-i} \\
& +\sum_{i=1}^{n} \mu_{i} \Delta \operatorname{LnEx}_{t-i}+\varphi_{1} \Delta \operatorname{Ln} \frac{\mathrm{Mdt}-\mathrm{i}}{\mathrm{Pt}-\mathrm{i}}+\varphi_{2} \operatorname{Ln} w_{t-1}+\varphi_{3} \pi_{t-1} \\
& +\varphi_{4} \operatorname{LnEx_{t-1}}+\varphi_{5} D U M_{t-1}+\mu_{t}
\end{aligned}
$$

The ARDL procedure contains two steps. First, the existence of the long-run relation between the variables in the system is tested. In other words, the null hypothesis of no cointegation or no long-run relationship defined by $\mathrm{H}_{0}$ : 
$\boldsymbol{\varphi}_{1}=\boldsymbol{\varphi}_{2}=\boldsymbol{\varphi}_{3}=\boldsymbol{\varphi}_{4}=0$ is tested for against its alternative $\mathrm{H}_{1}: \boldsymbol{\varphi}_{1} \neq \boldsymbol{\varphi}_{2} \neq \boldsymbol{\varphi}_{3} \neq \boldsymbol{\varphi}_{4} \neq 0$ by computing the F-statistics. The distribution of this F-statistics is non-standard irrespective of whether the variables in the system are $\mathrm{I}(0)$ or $\mathrm{I}(1)$. The two sets provide the bands covering all the possible classifications of the variable into $\mathrm{I}(0)$ or I(1), or even fractionally integrated ones. If the computed F-statistics is higher than the appropriate upper bound of the critical value, the null hypothesis of no cointegration is rejected; if it is below the appropriate lower bound, the null hypothesis cannot be rejected, and if it lies within the lower and upper bounds, the result is inconclusive.

\section{Result and Discussion}

\subsection{Estimation Result}

To begin with, the study carried out bound test to justify the existence of cointegration or long-run relationship among variables in the system. Table 1 shows the results.

Table 4.1 Bound test

\begin{tabular}{|c|c|c|c|c|}
\hline \multicolumn{2}{|l|}{ Test Statistic } & Value & \multicolumn{2}{|c|}{ K } \\
\hline F-statistic & & 5.109584 & \multicolumn{2}{|c|}{4} \\
\hline \multicolumn{5}{|c|}{ Critical Value Bounds } \\
\hline \multicolumn{2}{|l|}{ Significance } & I0 Bound & \multicolumn{2}{|c|}{ I1 Bound } \\
\hline $10 \%$ & & 2.45 & \multicolumn{2}{|c|}{3.52} \\
\hline $5 \%$ & & 2.86 & \multicolumn{2}{|c|}{4.01} \\
\hline $2.5 \%$ & & 3.25 & \multicolumn{2}{|c|}{4.49} \\
\hline $1 \%$ & & 3.74 & \multicolumn{2}{|c|}{5.06} \\
\hline \multicolumn{5}{|c|}{$\begin{array}{l}\text { It is clear from the results in table 1, that the F-statistics values are larger than I1 } \\
\text { bound value; hence, there is co-integration among these variables. Based on this } \\
\text { we proceeded to analysed the ARDL model. The results are showed in table } 2 \\
\text { Table } 4.2 \text { Result of ARDL Test }\end{array}$} \\
\hline Variables & Coefficients & Standard Error & t-statistics & Prob. \\
\hline $\operatorname{Ln}(\mathrm{MD} / \mathrm{p})_{\mathrm{t}-1}$ & 0.456127 & 0.035099 & 3.376242 & $0.0057^{* * *}$ \\
\hline LnW & 0.796735 & 0.337660 & 2.359579 & $0.0504^{* *}$ \\
\hline $\mathrm{LnPt}$ & 0.873534 & 0.429805 & 2.032394 & $0.0816^{*}$ \\
\hline LnEX & 3.002673 & 9.104417 & 0.329804 & 0.7512 \\
\hline DUMt & 0.201157 & 0.889426 & 0.226165 & 0.8275 \\
\hline $\mathrm{C}$ & -24.00150 & 73.85354 & -0.324988 & 0.7547 \\
\hline
\end{tabular}

Adjusted R-squared $=0.956568$, S.E. of regression $=0.337643$, Durbin-Watson stat $=2.811406$ 
$\operatorname{Prob}($ F-statistic $)=0.000039,{ }^{* * *},{ }^{* *}$ and ${ }^{*}$ indicates significance at $1 \%, 5 \%$ and $10 \%$ respectively. The results from the ARDL model shows that money demand, income and the general price level (inflation) is significant 1\%,5\% and 10\% respectively, however the political situations is not significant.

The study also carried out the serial correlation and heteroskedasticity test to determine whether the variables are serial correlated and also has heteroskedasticity and perhaps whether the model is good. Table 3 below shows the results.

Table 4.3 Breusch-Godfrey Serial Correlation LM Test

\begin{tabular}{llll}
\hline F-statistic & 2.003405 & Prob. F(2,5) & 0.2296 \\
Obs*R-squared & 8.452424 & Prob. & Chi- 0.0146 \\
& & Square(2) & \\
\hline
\end{tabular}

Table 4.4 Heteroskedasticity Test: Breusch-Pagan-Godfrey

\begin{tabular}{llll}
\hline F-statistic & 1.472477 & Prob. F(11,7) & 0.3122 \\
Obs*R-squared & 13.26656 & Prob. Chi-Square(11) & 0.2763 \\
Scaled explained & 1.768367 & Prob. Chi-Square(11) & 0.9992 \\
SS & & &
\end{tabular}

From table 4.3, it's clear from Breusch-Godfrey serial correlation LM test that the variables are serially correlated (the p-value $0.0146>5 \%$ ) this may be due to the mixture of the variables. However, heteroskedasticity does not exist.

To confirm the stability of the estimated model, the tests of CUSUM and CUSUMS of squares are employed in this research paper. Figure 2 and 3 respectively provide the graphs of CUSUM and CUSUMS of squares tests. Figure 4.1(a) indicates that the plot of CUSUM is completely stable within $5 \%$ of critical bands. Figure 4.1(b) we can see that it's nice within the 5\% significance boundary so we can say the model is stable.

Figure 4.1 Result of CUSUM and CUSUMQ Test

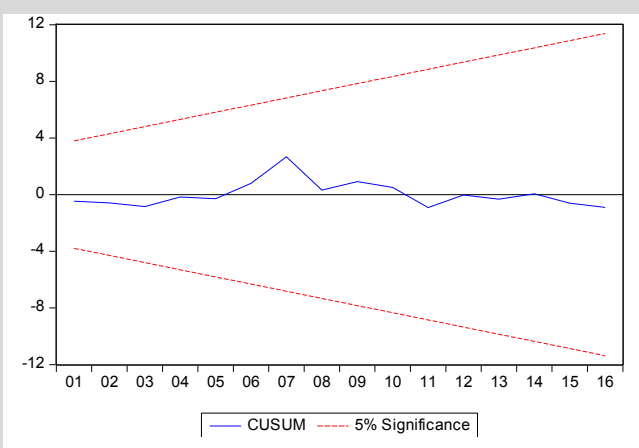

(a)

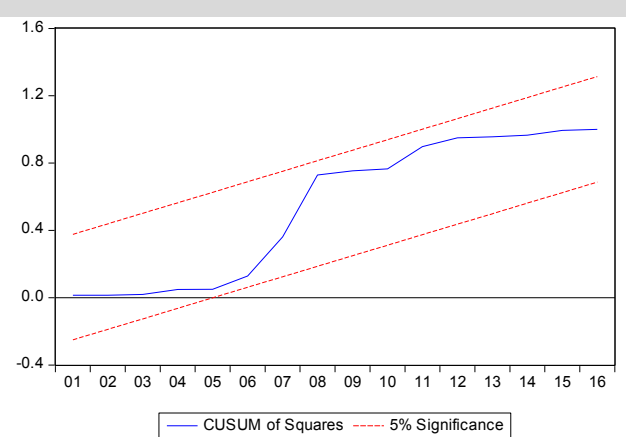

(b) 
Table 4.4 provides the results of error correction representations of the estimated ARDL model. As expected, the ECM term, here represented as EC ( $t$ 1 ), is negative with an associated coefficient estimate of -1.740655 . This implies that about $17.40 \%$ of any movements into disequilibrium are corrected for within one period. Moreover, given the very large t-statistic, namely -6.958481 , we can also conclude that the coefficient is highly significant.

Table 4.4, Results of Error Correlation of ARDL Model

Dependent variable Ln (M/P)

\begin{tabular}{lcccc}
\hline \multicolumn{1}{c}{ Variables } & Coefficients & Standard Error & t-statistics & Prob. \\
\hline$\Delta$ LnWt & 24.180233 & 6.871406 & 3.518965 & $0.0097^{* * *}$ \\
$\Delta \mathrm{LPt}$ & -9.933596 & 3.454837 & -2.875272 & $0.0238^{* *}$ \\
$\Delta \mathrm{LnEXt}$ & -0.206589 & 0.084178 & -2.454187 & $0.0438^{* *}$ \\
$\Delta \mathrm{DUMt}$ & 127.760835 & 67.869059 & 1.882461 & 0.1018 \\
EC $\mathrm{t}-1$ & -1.740655 & 0.250149 & -6.958481 & $0.0002^{* * *}$ \\
\hline
\end{tabular}

Adjusted R-squared $=0.459169, \mathrm{R}$-squared $=0.789677, \Delta=$ first difference *** and ${ }^{* *}$ indicates significance at $1 \%, 5 \%$ and $10 \%$ respectively.

The results also show that national income, inflation and exchange rates are statistically significant at $1 \%$ and $5 \%$ respectively. This implies that a percentage change in the significant variables will lead to a percentage increase or decrease in the real money demand according to the sign and coefficients of each of the variables in the short run. The dummy variable representing the political turmoil in Cambodia were found to be insignificant.

Table 4.5 Long run coefficients. Dependent variable $\operatorname{Ln}(\mathrm{MD} / \mathrm{P})$

\begin{tabular}{lcccc}
\hline Variables & Coefficients & Standard Error & t-statistics & Prob. \\
\hline LnW & 19.406361 & 6.155168 & 3.152856 & $0.0161^{* *}$ \\
LnP & 6.719734 & 4.909967 & 1.368590 & 0.2134 \\
LnEX & -0.030087 & 0.029540 & -1.018532 & 0.3423 \\
DUM & 51.587163 & 53.330407 & 0.967312 & 0.3656 \\
C & 107.064771 & 119.350070 & 0.897065 & 0.3995 \\
\hline
\end{tabular}

From the long run coefficients displayed in table 5, it is confirmed from this studies that only national income influences real money demand in the long run in Cambodia as it's significant at $5 \%$ level. This means that a percentage point increase in national income will lead to $19.41 \%$ increase in the real money demand in Cambodia. 


\subsection{Graphical Discussions}

Money supply in Cambodia continued to grow at a sustainable rate and did not put additional inflationary pressure on the economy. Money supply has been cautiously managed to support the demand of money in the economy and to maintain the resilience of the banking sector.

Figure 4.1 Money Growth in Cambodia

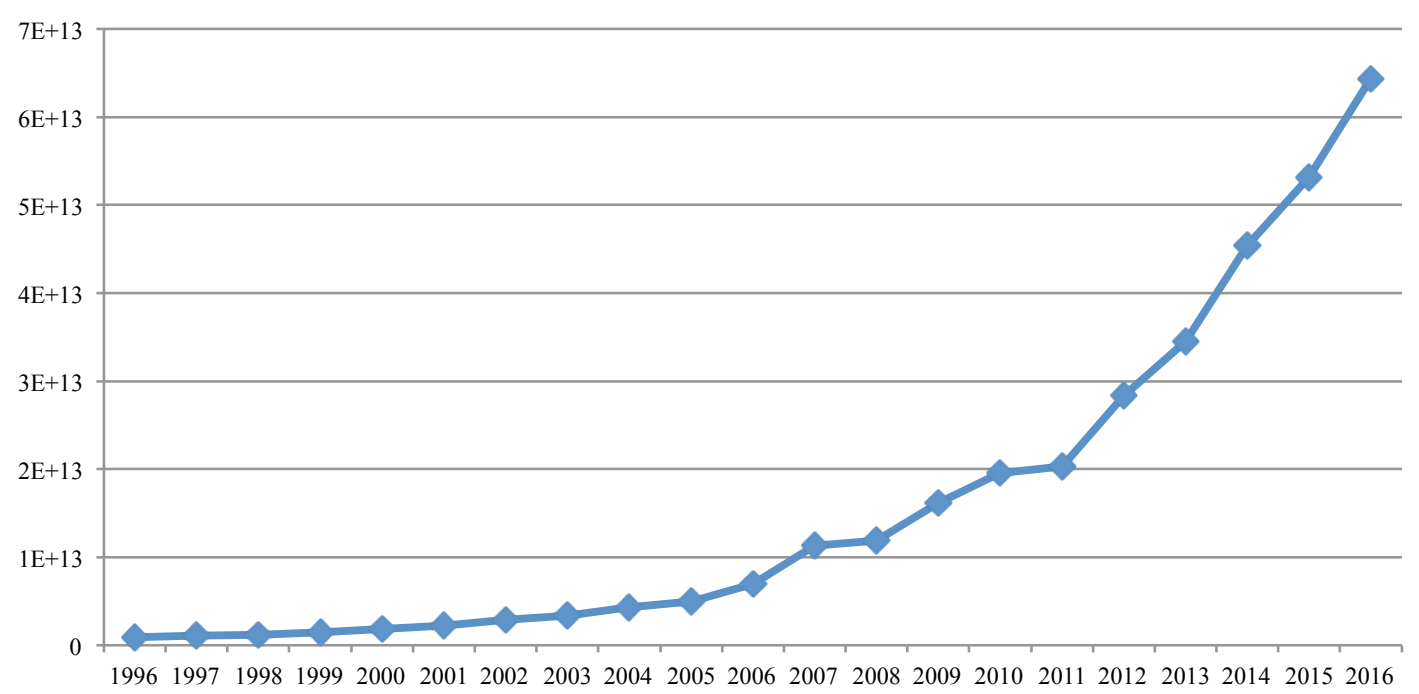

Source: Data from World Bank

Figure 4.1 shows the money supply in Cambodia from 1996 to 2016 which use data from World Bank. The money supply is a major variable that affects money demand. The graph shows that money supply in Cambodia has been increasing from $1996-2016$.

Figure 4.2 The Dynamics of Inflation Rate in Cambodia

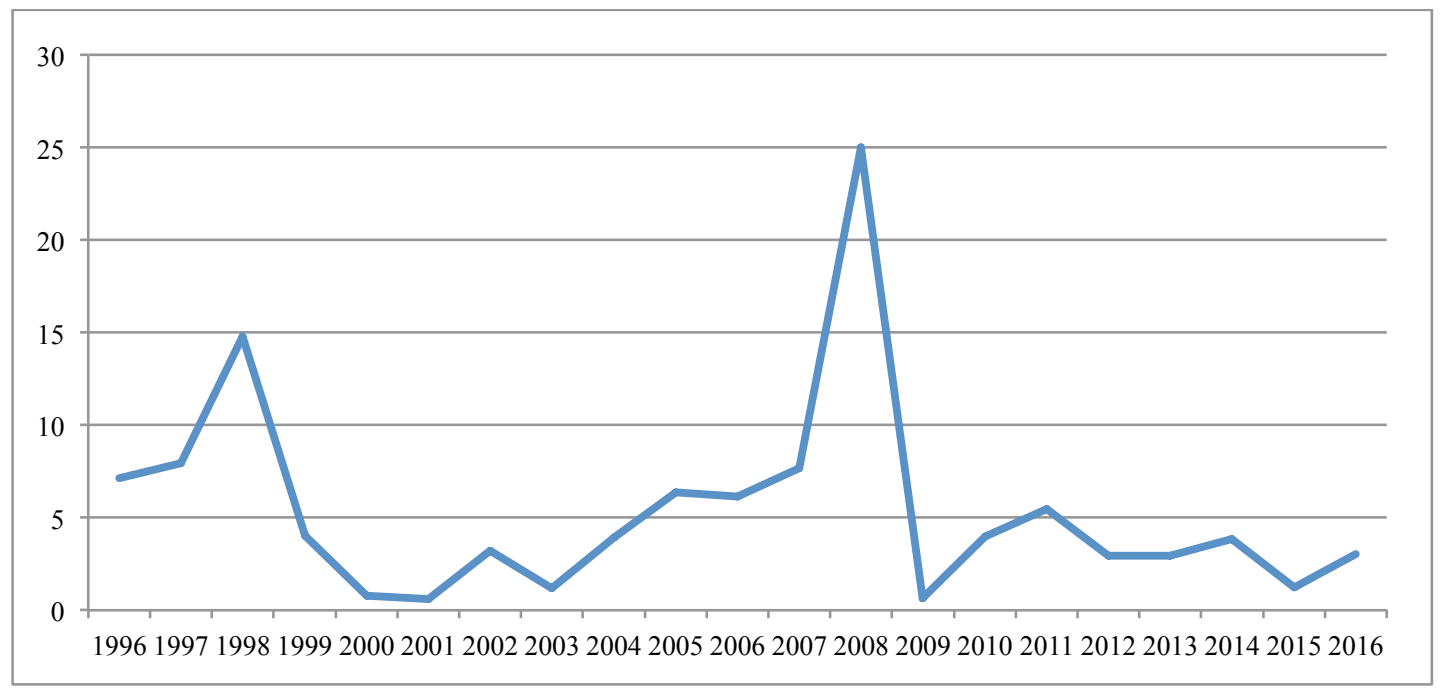

Source: Data from World Bank 
According to the data of World Bank as show in the figure 4.2 the inflation in Cambodia was up and down and had higher inflation rate during 2008-2009. The Friedman's Theory for Demand Money "Price level also determines the demand for money balances. A higher price level means people will require a larger nominal money balance in order to do the same amount of transactions, that is, to purchase the same amount of goods and services".

Figure 4.3 Official Exchange Rate in Cambodia (LCU per US\$, period average)

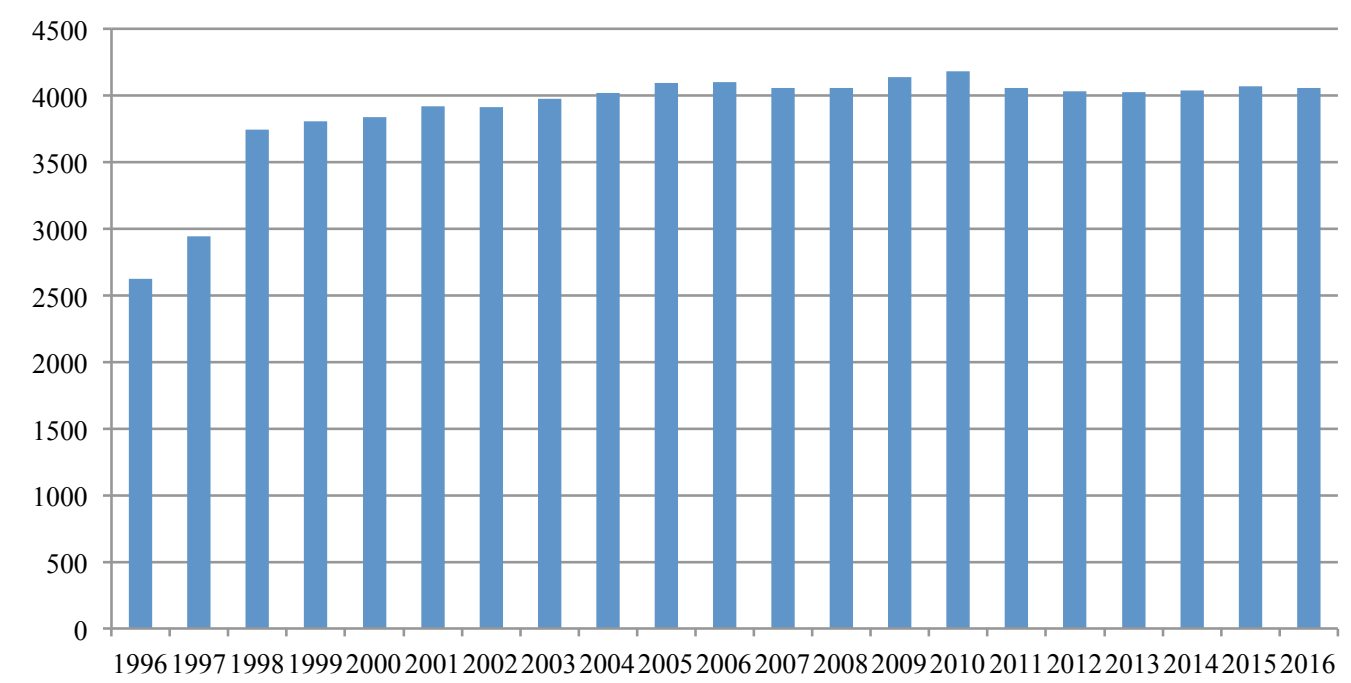

Source: Data from World Bank

The above graph shows exchange rate of Cambodian currency (Riel) and USD dollar from 1996 to 2016. The graph further indicates that exchange rate is quite stable over the study period.

\section{Figure 4.4 The money growth and Inflation rate in Cambodia}

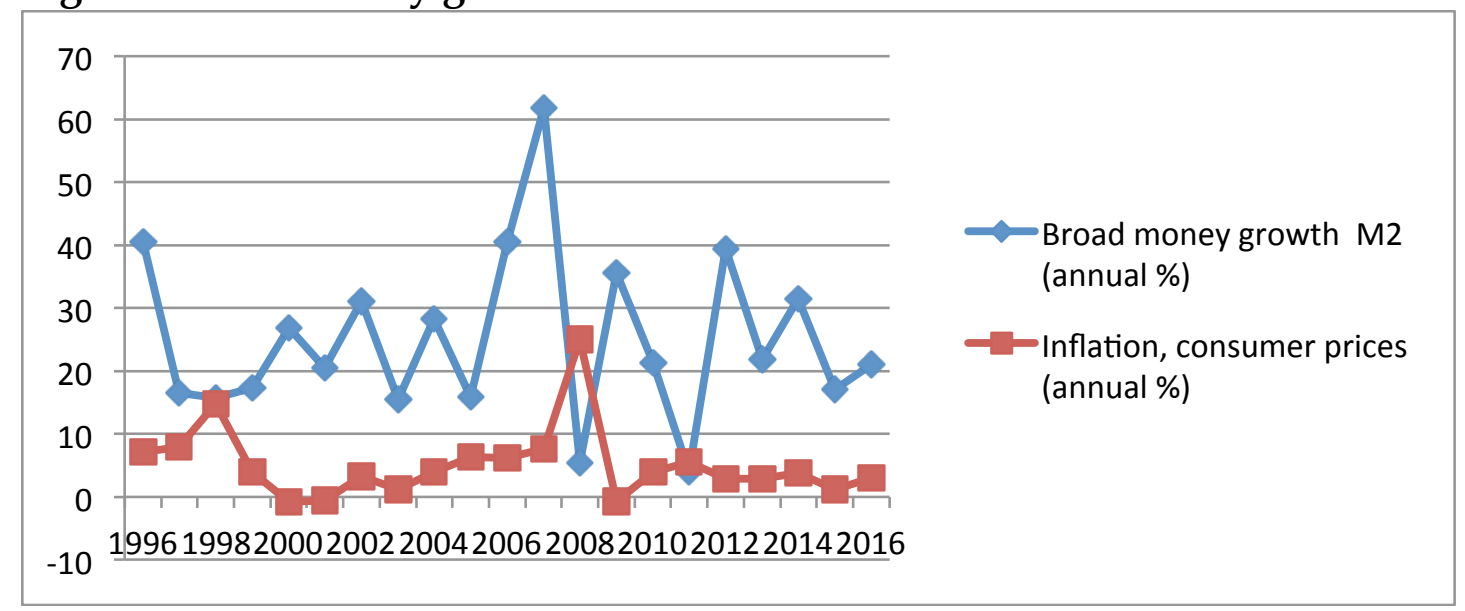

Source: Data from World Bank 
The figure 4.4, show about the comparing between money growth and inflation rate in Cambodia from 1996 to 2016. The graph above showed that the fluctuation of both graph is mixer of directions. In 2008 the inflation rate was high but the money growth was quite low. We expect inflation and money growth to have some positive relationships; an increased in money supply causes inflation to rise. However, money growth and inflation exhibit both positive and negative relationships in period considered, this seemingly variations are best explained by economic activities or phenomena during the period investigated.

\section{Conclusion}

By using the ARDL Model to analyse the stability of the money demand in Cambodia, the model confirms that the inflation rate, exchange rate is impact to money demand. Moreover, to confirm the stability of the model, the CUSUM and CUSUMSQ test are also conducted with the result that the estimated model is stable. In this term paper, the demand for money in Cambodia has been estimated using ARDL approach to cointegration analysis of Perasan. The ARDL method does not generally require knowledge of the order of integration of variables. The empirical results have shown that, most of variables in the model are statistically significant and consistent with the demand theory both in the long-run as well as in the short-run; however, some variables are found to be slightly inconsistent with the demand theory. In most instances there are explanations for this incidence.

The empirical analysis based on the bounds test, supports the stable money demand model for Cambodia. In fact, it shows that the existence of the long-run money demand equation can only be firmly established when inflation rate, exchange rate is included in the model. The negative effect of inflation rate on money demand supports our theoretical expectation that as the inflation rate rises, the demand for money falls. Furthermore, by applying the CUSUM and CUSUMSQ tests to the model, we show that long-run money demand model in Cambodia is more stable if inflation rate, exchange rate is included in the model. 


\section{References}

Akinlo, A Enisan. (2006), The stability of money demand in Nigeria: An autoregressive distributed lag approach"Journal of Polic Modeling, 28(4): 445-452.

Bahami-Oskooee, M.(1996) The black Market Exchange Rate and Demand for money in Iran, Journal of Macroeconomic 18: 171-176

Frederirc S.Mishkin, the theory of money demand, text book The Economic of Money, Bank\& Financial Market, ninth edition P (500)

Friedman, M (1970). "A theoretical framework for monetary analysis"Journal of Political Economy, 78(2): 193-238

John Maynard Keynes, 1936, theory of money demand

Pesaran, M. H, Shin, Y, Smith R. J.(2001), "Bounds testing approaches to the analysis of level relationships" Journal of Applied Econometrics, 16: 289326

Samreth, S. (2008) Currency substitution and Seigniorage- Maximizing Inflation: The cause of Cambodia Applied Economic.

Wold Bank, the data from 1996-2016 